\title{
Dissociable Hormonal, Cognitive, and Mood Responses to Neuroendocrine Challenge: Evidence for Receptor-Specific Serotonergic Dysregulation in Depressed Mood
}

\author{
Gary Wand*,' and Lynn Oswald' \\ 'The Johns Hopkins University School of Medicine, Baltimore, MD, USA
}

Neuropsychopharmacology (2003) 28, I0II, advance online publication, 19 March 2003; doi: I0.1038/sj.npp. 1300077

Sir

We read with interest the manuscript by Riedel and colleagues (2002, 26: 358-367) in which the authors compare hypothalamic-pituitary-adrenal (HPA) responses to the 5HT2c agonist, m-CPP and the 5-HT1A agonist, ipsapirone. Both 5-HT agonists significantly elevated ACTH and cortisol. The cortisol response to ipsapirone was significantly blunted in patients with major depression compared to controls whereas cortisol responses to m-CPP did not differ between groups. Moreover, m-CPP selectively increased depression and tenseness symptoms as assessed by the profile of mood states (POMS) whereas ipsapirone did not.

Excitation of the serotonin system activates the HPA axis by first stimulating CRH secretion, which then stimulates the release of adrenocorticotropin (ACTH) from the pituitary gland. In turn, ACTH stimulates cortisol release from adrenal cortex. There is an implicit but faulty assumption that serotonin agonists regulate the HPA axis solely through central nervous system mechanisms. The authors suggest that the differential action of $\mathrm{m}-\mathrm{CPP}$ and ipsapirone on cortisol levels reflects different expressions of 5HT modulation in hypothalamic (hormonal) and amygdalo-frontal (mood) pathways (Stahl, 1998). However, the authors' data suggest otherwise showing that the differential cortisol response to the two 5HT agonists must include actions at a peripheral site, outside the CNS. For example, m-CPP causes a peak ACTH response of $\sim 11 \mathrm{ng} / \mathrm{l}$, which then induces a peak cortisol level of $250 \mathrm{nmol} / \mathrm{l}$, whereas in the same group of patients, ipsapirone induces a three-fold higher level of ACTH than $\mathrm{m}$-CPP, but is followed by a peak cortisol level of only $\sim 150 \mathrm{nmol} / \mathrm{l}$. A similar paradox is observed in the control group if only a central mechanism is invoked to explain the differential effects of both agents on cortisol release.

\footnotetext{
* Correspondence: Dr GS Wand, The Johns Hopkins University School of Medicine, Ross Research Bldg Room 850, 720 Rutland Avenue, Baltimore, MD, USA, E-mail: gwand@welch.jhu.edu

Received 28 February 2002; accepted 24 September 2002

Online publication: 27 September 2002 at http://www.acnp.org/ citations/Npp092702396
}

The discrepancy between the ACTH /cortisol ratio following administration of each 5-HT agonist can only be explained by the differential peripheral action of the two agents. Cortisol responds in a dose-dependent manner to ACTH. Therefore, it is not possible to explain the differential effects of $\mathrm{m}$-CPP and ipsapirone on the ACTH/cortisol ratio merely through CNS mechanisms. Instead one would have to posit that the mechanism accounting for the differences in the ACTH/cortisol ratio induced by both 5-HT agonists is occurring at the level of the adrenal gland. Specifically, the data suggest that m-CPP increases cortisol release not only by stimulating ACTH secretion but also by acting directly at the level of the adrenocortical cell (Contesse et al, 2000; Lefebvre et al, 1998). Alternatively, the differential effects on cortisol release could be produced if ipsapirone both stimulates ACTH release and attenuates the action of ACTH on cortisol secretion. However, we are unaware of any data showing that activation of a 5-HT receptor subtype partially antagonizes the effects of ACTH on cortisol release.

Before mechanistic conclusions can be drawn from such challenge protocols, we propose that future studies take into account the peripheral as well as the central effects of serotonergic agents on the HPA axis.

\section{REFERENCES}

Contesse DC, Lefebvre H, Lenglet S, Kuhn JM, Delarue C, Vaudry $\mathrm{H}$ (2000). Role of 5-HT in the regulation of the brain-pituitaryadrenal axis: effects of 5HT in adrenocortical cells. Can J Physiol Pharmacol 78: 967-983.

Lefebvre H, Contesse V, Delarue C, Vaudry H, Kuhn JM (1998). Serotonergic regulation of adrenocortical function. Horm Metab Res 30: 398-403.

Riedel WJ, Klaassen T, Griez E, Honig A, Menheere PP, van Praag HM (2002). Dissociable hormonal, cognitive, and mood responses to neuroendocrine challenge: evidence for receptorspecific serotonergic dysregulation in depressed mood. Neuropsychopharmacology 26: 358-367.

Stahl SM (1998). Mechanism of action of serotonin selective reuptake inhibitors. Serotonin receptors and pathways mediate therapeutic effects and side effects. J Affect Disord 51: 215-235. 